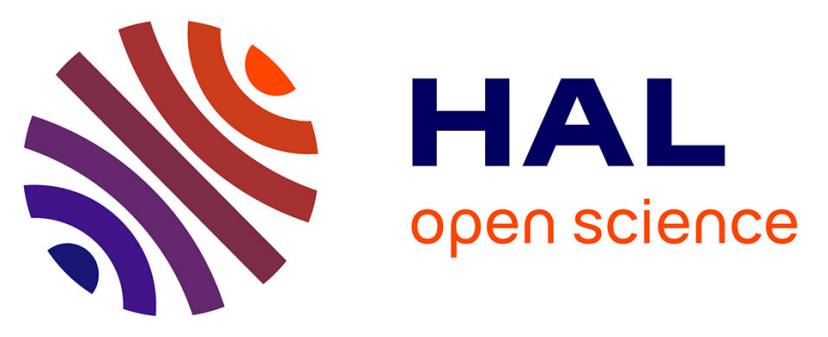

\title{
Methane oxidation in a biofilter (Part 1): Development of a mathematical model for designing and optimization
}

Corrado Amodeo, Salvatore Masi, Stijn W H van Hulle, Pierfrancesco Zirpoli, Ignazio Mancini, Donatella Caniani

\section{- To cite this version:}

Corrado Amodeo, Salvatore Masi, Stijn W H van Hulle, Pierfrancesco Zirpoli, Ignazio Mancini, et al.. Methane oxidation in a biofilter (Part 1): Development of a mathematical model for designing and optimization. Journal of Environmental Science and Health, Part A, 2015, 50 (13), pp.1393-1403. 10.1080/10934529.2015.1064277 . hal-02010877

\section{HAL Id: hal-02010877 https://hal.science/hal-02010877}

Submitted on 21 Feb 2019

HAL is a multi-disciplinary open access archive for the deposit and dissemination of scientific research documents, whether they are published or not. The documents may come from teaching and research institutions in France or abroad, or from public or private research centers.
L'archive ouverte pluridisciplinaire HAL, est destinée au dépôt et à la diffusion de documents scientifiques de niveau recherche, publiés ou non, émanant des établissements d'enseignement et de recherche français ou étrangers, des laboratoires publics ou privés. 
Methane oxidation in a biofilter (part 1):

development of a mathematical model for designing and optimization

\author{
CORRADO AMODEO ${ }^{1,2 *}$, SALVATORE MASI ${ }^{1}$, STIJN W.H. VAN HULLE ${ }^{2}$, PIERFRANCESCO \\ ZIRPOLI $^{1}$, IGNAZIO M. MANCINI ${ }^{1}$ and DONATELLA CANIANI ${ }^{1}$ \\ ${ }^{1}$ School of Engineering, University of Basilicata - Viale dell'Ateneo Lucano - 85100 Potenza (Italy) \\ ${ }^{2}$ Department of Industrial Biological Sciences, Ghent University Campus Kortrijk, Graaf Karel de \\ Goedelaan, 5 - 8500 Kortrijk (Belgium)
}

\footnotetext{
*Address correspondence to Corrado Amodeo, Department of Industrial Biological Sciences, Ghent University Campus Kortrijk, Graaf Karel de Goedelaan, 5 - 8500 Kortrijk (Belgium); Phone: +32 493673719; Fax: +32 56241224;

E-mail: corrado.amodeo@unibas.it
} 


\section{Abstract}

Landfill gas is produced by anaerobic degradation of organic waste. Landfills are one of the principal anthropogenic sources of atmospheric methane, a strong greenhouse gas ${ }^{[1]}$. Landfills, in particular, have been found to be a principal source of $\mathrm{CH}_{4}$ production. The $\mathrm{CH}_{4}$ emission from the waste sector is about $18 \%$ of the global anthropogenic $\mathrm{CH}_{4}$ emission ${ }^{[2]}$. For small landfills or landfills in advanced stages of post management (with methane percentage below $30 \% \mathrm{v} / \mathrm{v}$ ) biofilters are an interesting sustainable alternative. The aim of this work is the evaluation of the efficiency of such a biofilter, through the application of a mathematical model which describes the biological oxidation process. This mathematical model is able to predict the efficiency of the system under varying operating conditions. Literature data have been used in order to build the model. The factors that mostly affect the process and which actually regulate the entire process have been highlighted in this work. Specifically, it was found that temperature, flow and methane concentration are the most important parameters that influence the system. The results obtained from the mathematical model showed also that the biofilter system is simple to implement and manage and allows the achievement of high efficiency of methane oxidation. In the optimal conditions for temperature (between $20-30{ }^{\circ} \mathrm{C}$ ), residence time (between 0.7-0.8 h) and methane molar fraction (between 20-25\%) the efficiency of methane oxidation could be around $50 \%$.

Keywords: Methane oxidation, methane emission, landfill gas, methanotrophs microorganisms, biofilters. 


\section{Introduction}

\section{Landfill gas (LFG)}

A series of control and abatement systems must be provided to minimize the environmental impact that may derive from landfills (during the management or during the post-management). In the landfills the decomposition processes of organic substances under anaerobic conditions lead to the production of biogas which is usually composed mainly of methane $\left(\mathrm{CH}_{4}\right)$ and carbon dioxide $\left(\mathrm{CO}_{2}\right)^{[3]}$. Both are classified as greenhouse gases. In the atmosphere the concentration of $\mathrm{CH}_{4}$ has increased from a pre-industrial value of about 715 to 1732 parts per billion (ppb) in the early 1990s, and was $1774 \mathrm{ppb}$ in 2005. The atmospheric concentration of $\mathrm{CH}_{4}$ in 2005 far exceeded the natural range of the last 650000 years (320 to $790 \mathrm{ppb}$ ) as determined from ice cores ${ }^{[4]}$. In the last years the values of methane concentration are due to continuing anthropogenic $\mathrm{CH}_{4}$ emissions. Several studies, such as Forester et al. ${ }^{[1]}$ have demonstrated that the contribution of methane to climate change is $18 \%$ of the total radiative forcing by all long-lived greenhouse gases. In the United States the methane originated from landfills is the second largest anthropogenic $\mathrm{CH}_{4}$ emission source: the emission of $\mathrm{CH}_{4}$ from US landfills in 2007 was about $6.329 \mathrm{Tg}^{[5]}$. Also in Europe, in 2006, the methane from landfills was the second largest source of anthropogenic $\mathrm{CH}_{4}(22 \%)$ with an estimated $\mathrm{CH}_{4}$ emission of $3.373 \mathrm{Tg}$ from waste disposal ${ }^{[6]}$. If the contribution of all the landfills in the world is considered, the amount of methane released is between 35 and $69 \mathrm{Tg}$ year ${ }^{-1}$ of $\mathrm{CH}_{4}{ }^{[2]}$. Obviously all these data do not originate from measurements on site but are projections based on estimated rates of $\mathrm{CH}_{4}$ production in relation with the national statistics about (landfilled) waste ${ }^{[3]}$.

\section{LFG treatment}

The contribution of $\mathrm{CH}_{4}$ to global GHG emissions is important and for this reason worldwide most of legislative systems provide several treatments for the municipal waste before or in alternative to the landfill disposal ${ }^{[7]}$. As a consequence of the large contribution of LFG to the global greenhouse 
gas production, most of the industrialized countries have imposed legislation for the extraction and treatment of landfill gas, especially in recently constructed installations.

In the large and young landfills the energy recovery systems represent the best solution to treat the landfill gas but it need large quantity of LFG flow rate and a high enough methane content. Flares are another solution to treat the biogas, oxidizing $\mathrm{CH}_{4}$ through combustion. Technical specifications for the operation of gas flares available on the market indicate a minimum flow of $50 \mathrm{Nm}^{3} / \mathrm{h}$ and a methane concentration of $30 \% \mathrm{v} / \mathrm{v}$ (as is shown in a normal catalogue of flares ${ }^{[8]}$ ). When the flow is less than $50 \mathrm{Nm}^{3} / \mathrm{h}$ or the methane concentration of the biogas is less than $30 \% \mathrm{v} / \mathrm{v}$ the biofiltration represent a good way to treat the biogas.

The biofilter is an aerobic reactor that can be used for treatment of landfill gas by methane oxidation, so called microbial aerobic methane oxidation (MAMO). The biofilter contains microorganisms able to convert the methane to carbon dioxide ${ }^{[3]}$. In the biofilter the filling material supports and sustains the development of a methanotrophic biofilm. As usual the biofiltration costs (both investment and management) decrease relatively with increasing size of the biofilter. The average investment costs of a biofilter of 10,20 , and $40 \mathrm{~m}^{3}$ are $€ 1300, € 1100$, and $€ 800$ per $\mathrm{m}^{3}$ of reactor, respectively. The operational costs, including both fixed and variable costs, are $€ 190, €$ $160, € 124$ per $\mathrm{m}^{3}$ of reactor per year, respectively ${ }^{[9]}$.

There are two different biofilter systems: upflow or downflow. The upflow system, if it work as an open bed, allows the presence of atmospheric oxygen. The extraction of LFG may be active or passive. For the active system, the LFG extracted from the landfill is supplied to the biofilter and so it is possible to control the influent flow. Air and LFG can be combined before entering in the system $^{[10-11]}$, or two different feed lines can be used ${ }^{[12]}$. Air may also enter in the biofilter by diffusive transport across the column surface ${ }^{[13]}$. The systems with active feeding works usually with constant temperature and water content and so a power supply is needed. It is more complicate to manage this kind of systems so often these systems are housed to facilitate the control over the operational parameters. On the other side, in the passive systems, the LFG comes in when there is a 
pressure gradient between the landfill and the atmosphere. In these conditions the gas passes through collection piping up to arrive in the biofilter ${ }^{[14-15-16]}$. When the pressure gradients are not high the diffusion process may play an important role, while the $\mathrm{O}_{2}$ is supplied to the system or by advection when the pressure rises or by diffusion from the atmosphere across the biofilter surface ${ }^{[16]}$. So the weak point of passive systems is that the operating conditions are not manageable, but on the other side all the costs (capital and operating) are considerably lower in relation with active systems $^{[3]}$.

\section{Methane oxidation kinetics}

The process of microbial aerobic methane oxidation (MAMO), according to Chanton et al. ${ }^{[17]}$ and $\mathrm{Ng}$ et al. ${ }^{[18]}$, is regulated by the following biochemical reaction $\left(\Delta^{\circ} \mathrm{G}=-780 \mathrm{~kJ} \mathrm{~mol}^{-1} \mathrm{CH}_{4}\right.$, $\left.\Delta^{\circ} H=-890 \mathrm{~kJ} \mathrm{~mol}^{-1}\right)$ :

$$
\mathrm{CH}_{4}+(2-x) \mathrm{O}_{2} \rightarrow(1-x) \mathrm{CO}_{2}+(2-x) \mathrm{H}_{2} \mathrm{O}+\text { heat }
$$

Where $\mathrm{x}$ is the stoichiometric coefficient. The kinetics that occurs is described by MichaelisMenten kinetics for methane and oxygen ${ }^{[3-18-19]}$ :

$$
r=\frac{V_{\max } \cdot y_{C_{4}}}{K_{m}^{C H_{4}}+y_{C H_{4}}} \cdot \frac{y_{o_{2}}}{K_{m}^{O_{2}}+y_{o_{2}}}
$$

Where:

- $r=\mathrm{CH}_{4}$ oxidation rate $\left[\mathrm{mol} /\left(\mathrm{m}^{3} * h\right)\right]$;

- $V_{\max }=$ maximum $\mathrm{CH}_{4}$ oxidation rate $\left[\mathrm{mol} /\left(\mathrm{m}^{3} * h\right)\right]$;

- $K_{m}=$ Michaelis-Menten (or half-saturation) constant [dimensionless];

- $y_{\mathrm{CH} 4}=$ molar fraction of $\mathrm{CH}_{4}$ in the biofilm[dimensionless];

- $y_{\mathrm{O} 2}=$ molar fraction of $\mathrm{O}_{2}$ in the biofilm [dimensionless].

The methanotrophic bacteria are aerobic bacteria, so require the presence of oxygen in order to convert methane into carbon dioxide. The oxygen concentration is an important parameter: the 
efficiency of methane oxidation is near the maximum when oxygen concentration reached $5 \% \mathrm{v} / \mathrm{v}$, and then keep a stable value when it reached $21 \% \mathrm{v} / \mathrm{v}^{[20]}$. If the concentration is under this threshold there will be a rapid decrease of the conversion rates of methane.

As all the biological reaction there are several environmental factors that control the methane oxidation (e.g soil texture, temperature, soil moisture content, methane and oxygen supply, nutrients, etc.). Thus, all the environmental conditions are very important for the methane oxidation rate and should therefore be included in the kinetic model. A main role is played by the temperature that has a profound effect on all biological processes, including methane oxidation activity. Most of methanotrophs bacteria are mesophiles so their optimum temperature is around $25-35{ }^{\circ} \mathrm{C}{ }^{[3]}$. However, methane oxidation can occur down to $1-2{ }^{\circ} \mathrm{C}^{[21]}$.

Another important factor for micro-organisms is certainly the moisture, as transport medium for nutrient supply and also for removal of residual metabolic compounds ${ }^{[22]}$. So the efficiency of the methane oxidation depends of the moisture contents of the system: low and high water contents can limit the process. If the moisture is high the gaseous transport processes in the soil may slow down (molecular diffusion in water is about $10^{4}$ times slower than in the air ${ }^{[23]}$ ). Indeed, if the soil's degree of saturation (that represent the ratio between the volume of water and the volume of voids) reaches high values (e.g. 85\%), the air filled voids are no longer interconnected. In these conditions the gases must diffuse in the liquid phase, and this means that the methane and oxygen availability is drastically reduced, limiting the oxidation process. On the other side if the moisture content decreases the oxidation efficiency may also reduce significantly due to water stress in the system. When the soil conditions are optimum in term of moisture content the oxidation process can occur with good results. The specific value obviously is function of the specific characteristics of the biofilter; generally in the range between $10-20 \% \mathrm{w} / \mathrm{w}$. The threshold value is $5 \%$ : if the moisture content drops below this value then the oxidation activity is drastically reduced. 
Another important parameter for the success of the process that plays an important role is the $\mathrm{pH}$, as in the most of reactions. The optimal $\mathrm{pH}$ for the methane oxidation and so for the methanotrophic bacteria development is between 5.5 and $8.5^{[3]}$.

\section{MAMO modelling}

Bogner et al. ${ }^{[24]}$ developed a dynamic model for landfill gas transport and methane oxidation in landfill cover soils in terms of molecule collisions with the soil matrix. Hilger et al. ${ }^{[25]}$ developed a model based on the well-established Stefan-Maxwell equations. Stein et al. ${ }^{[26]}$ developed a model for simulating 1D transport and biological reaction of methane in porous media. De Visscher et al. ${ }^{[27]}$ developed a simulation model that describes gas transport and methane oxidation in a laboratory setup. Hettiarachchi et al. ${ }^{[28]}$ and Hettiarachchi et al. ${ }^{[29]}$ did a comprehensive one-dimensional mathematical model that incorporates heat transfer and moisture transport in methane biofilters. $\mathrm{Ng}$ et al. ${ }^{[18]}$ developed a model that incorporates water, gas and heat coupled reactive transport in unsaturated soil and Abichou et al. ${ }^{[30]}$ used a numerical model that combines flow of water and heat with gas transport. Such models provide a practical tool for prediction of net methane conversion and they also allow a sensitivity analysis of the most important parameters. The main difference between the model presented in this study and existing models is that most of these models refer to the process of methane oxidation that occurs in landfill covers and not in biofilters. In the latter case all the gases enter from the bottom of the system (already premixed). Other differences are the choice of diffusion coefficients to explain the transport phenomena and the use of two dimensionless numbers to solve the model equations. Therefore, in this study, a novel model was developed.

\section{Aim of the study}

The aim of this work is the evaluation of the efficiency of a biofilter, through the application of the above mentioned novel mathematical model which incorporates the effects on the biological 
oxidation process. This mathematical model will be used to give some practical information to design and manage a biofilter for landfills.

\section{Materials and methods}

\section{Reaction and reactor model}

The simplifying assumption for the implementation of the mathematical model (in Matlab®) is that the biofilter is an ideal plug flow reactor (PFR) with complete mixing in the transverse direction and that the gas mixture consists of only $\mathrm{CH}_{4}, \mathrm{O}_{2}, \mathrm{CO}_{2}$ and $\mathrm{N}_{2}$. All the gases, including oxygen, enter from the bottom of the biofilter (Fig. 1). The nitrogen was not considered in the model (as it is inert in MAMO).

For the three components $\left(\mathrm{CH}_{4}, \mathrm{O}_{2}, \mathrm{CO}_{2}\right)$ a steady state mass balance was set-up.

$$
\frac{d y_{\mathrm{CH}_{4}}}{d z}=-\frac{k_{g}^{C H} a}{Q}\left(y_{C H 4}-H_{C H 4} \cdot y_{C H 4}^{s}\right) \cdot S
$$

$$
\frac{d y_{O_{2}}}{d z}=-\frac{k_{g}^{O_{2}} a}{Q}\left(y_{O_{2}}-H_{O 2} \cdot y_{O_{2}}^{s}\right) \cdot S
$$

$$
\frac{d y_{\mathrm{CO}_{2}}}{d z}=\frac{k_{g}^{C O_{2}} a}{Q}\left(y_{\mathrm{CO}_{2}}-H_{\mathrm{CO} 2} \cdot y_{\mathrm{CO}_{2}}^{s}\right) \cdot S
$$

With:

- $Q=$ landfill flow rate entering in the biofilter $\left[\mathrm{m}^{3} / \mathrm{h}\right]$;

- $y=$ mole fraction in the gas phase;

- $y^{s}=$ mole fraction in the gas phase that reaches the biomass;

- $k_{g}=$ transport matter coefficient $[\mathrm{m} / \mathrm{h}]$;

- $\quad a=$ specific surface area $\left[\mathrm{m}^{2} / \mathrm{m}^{3}\right]$;

- $z=$ direction of the oxidation (i.e. biofilter height); 
- $\quad H_{C H 4}=$ Methane Henry's constant [dimensionless];

- $H_{O 2}=$ Oxygen Henry's constant [dimensionless];

- $H_{\mathrm{CO} 2}=$ Carbon Dioxide Henry's constant [dimensionless];

- $\quad S=$ effective surface of the filling material in which occurs the oxidation $\left[\mathrm{m}^{2}\right]$.

For the Henry's law constants the following values were used (values expressed as gas concentration/liquid concentration and supposed constant at different temperatures):

$H_{C H 4}=29.2 ; H_{O 2}=31.4 ; H_{C O 2}=1.19{ }^{[31]}$

The terms at the right hand side of the equations are related to the diffusion process that occurs within the system. Further, it can be assumed that the diffusion rate equals the reaction rate in the biofilm. The kinetics of the oxidation process are only dependent on the methane concentration at sufficiently high oxygen concentration as discussed above. Experimental data suggest that, if oxygen has a concentration value around $9 \%$, there is the maximum oxidation rate for the oxygen and the half-saturation constant has a value that is (very) low in relation to the oxygen molar fraction $\left(K_{m}^{O_{2}} \ll y_{\mathrm{O}_{2}}\right)$ therefore the oxygen term can be removed from the Equation $1^{[27]}$. As such the following equations are obtained.

$$
\begin{aligned}
& k_{g}^{C H 4} a \cdot C_{T O T}\left(y_{C H 4}-H_{C H 4} \cdot y_{C H 4}^{s}\right)=R_{C H 4}=\frac{V_{M A X} \cdot y_{C H 4}^{s}}{K_{m}^{C H}+y_{C H 4}^{s}} \\
& k_{g}^{O 2} a \cdot C_{T O T}\left(y_{O 2}-H_{O 2} \cdot y_{O 2}^{s}\right)=2 \cdot R_{C H 4}=2 \cdot \frac{V_{M A X} \cdot y_{C H 4}^{s}}{K_{m}^{C H}+y_{C H 4}^{s}} \\
& k_{g}^{C O 2} a \cdot C_{T O T}\left(y_{C O 2}-H_{C O 2} \cdot y_{C O 2}^{s}\right)=R_{C H 4}=-\frac{V_{M A X} \cdot y_{C H 4}^{s}}{K_{m}^{C H}+y_{C H 4}^{s}}
\end{aligned}
$$

Where $C_{T O T}=$ total concentration of moles in the gas phase $\left[\mathrm{mol} / \mathrm{m}^{3}\right]$;

Based on the equations above the change of the methane concentration in the biofilter height can be calculated as follows.

$$
y_{C H 4}^{s}=\frac{y_{C H 4}}{H_{C H_{4}}}-\left(\frac{R_{C H 4}}{k_{g}^{C H 4} a \cdot C_{T O T} \cdot H_{C H 4}}\right)
$$




$$
\begin{aligned}
& y_{O_{2}}^{s}=\frac{y_{O_{2}}}{H_{O_{2}}}-\left(\frac{2 \cdot R_{C_{4}}}{k_{g}^{O_{2}} a \cdot C_{T O T} \cdot H_{O 2}}\right) \\
& y_{\mathrm{CO}_{2}}^{s}=\frac{y_{\mathrm{CO}_{2}}}{H_{\mathrm{CO}_{2}}}-\left(\frac{R_{\mathrm{CH}_{4}}}{k_{g}^{\mathrm{CO}_{2}} a \cdot C_{\mathrm{TOT}} \cdot H_{\mathrm{CO} 2}}\right)
\end{aligned}
$$

\section{Dimensionless numbers}

Two dimensionless numbers were defined in order to describe the behavior of the biofilter. The Damköhler number $(\mathrm{Da})$ is a dimensionless number used to relate the reaction timescale (reaction rate) to the transport phenomena rate occurring. The Stanton number (St) is a dimensionless number used to relate the reaction timescale (reaction rate) to the diffusion phenomena rate occurring.

$$
\begin{aligned}
& D a=\frac{\text { residence time }}{\text { reaction time }}=\frac{t_{R E S .}}{t_{R E A}}=\frac{S \cdot h}{Q} / \frac{C_{T O T}}{R} \\
& S t=\frac{\text { residence time }}{\text { diffusion time }}=\frac{t_{R E S .}}{t_{D I F F}}=\frac{S \cdot h}{Q} / \frac{1}{k_{g} \cdot a}
\end{aligned}
$$

The ratio between both dimensionless numbers is:

$$
X=\frac{D a}{S t}=\frac{R}{C \cdot k_{g} \cdot a}
$$

Further, a new variable $(\omega)$ can be defined: $\omega=z / h$ where $h$ is the height of the filling material inside the biofilter: the effective oxidation height. Based on the dimensionless numbers, the set of equations above (2-3-4) can be rewritten accordingly (solving Equation $8 \mathrm{y}^{\mathrm{s}} \mathrm{CH} 4$ results in a quadratic equation and for physical reasons the negative solution was discarded). 


$$
\begin{aligned}
\frac{d y_{C H 4}}{d \omega}= & -S t_{C H 4} \cdot\left(y_{C H 4}-H_{C H 4} \cdot y_{C H 4}^{S}\right) \\
& -\left(\frac{X_{C H 4}}{H_{C H 4}}-\frac{y_{C H 4}}{H_{C H 4}}+K_{m}^{C H 4}\right)+\sqrt{\left(\frac{X_{C H 4}}{H_{C H}}-\frac{y_{C H 4}}{H_{C H}}+K_{m}^{C H 4}\right)^{2}+4 \frac{K_{m}^{C H 4} y_{C H 4}}{H_{C H}}} \\
y_{C H 4}^{S} & \frac{2}{1}
\end{aligned}
$$

$$
\begin{aligned}
& \frac{d y_{O 2}}{d \omega}=-S t_{O 2} \cdot\left(y_{O 2}-H_{O 2} \cdot y_{O 2}^{S}\right) \\
& y_{O 2}^{S}=\frac{y_{O 2}}{H_{O 2}}-2 \cdot \frac{X_{O 2}}{H_{O 2}} \cdot \frac{y_{C H_{4}}^{S}}{K_{m}^{C H_{4}}+y_{C_{4}}^{S}}
\end{aligned}
$$

$$
\begin{gathered}
\frac{d y_{\mathrm{CO} 2}}{d \omega}=S t_{\mathrm{CO} 2} \cdot\left(y_{\mathrm{CO} 2}-H_{\mathrm{CO} 2} \cdot y_{\mathrm{CO} 2}^{S}\right) \\
y_{\mathrm{CO} 2}^{S}=\frac{y_{\mathrm{CO} 2}}{H_{\mathrm{CO} 2}}-\frac{X_{\mathrm{CO} 2}}{H_{\mathrm{CO} 2}} \cdot \frac{y_{\mathrm{CH}_{4}}^{S}}{K_{m}^{C H_{4}}+y_{\mathrm{CH}_{4}}^{S}}
\end{gathered}
$$

Finally the degree of methane conversion $\left(x_{\mathrm{CH} 4}\right)$ was defined as:

$$
x_{C H_{4}}[\%]=\left(\frac{y_{C H_{4}, 0}-y_{C_{4}}}{y_{C_{4}, 0}}\right) \cdot 100
$$

\section{Determination of the model's parameters}

\section{Transport coefficient $k_{g}$}

The term $k_{g} * a$ that appears in the Equations 2, 3 and 4 is the volumetric transport coefficient. Seongyup Kim et al. ${ }^{[32]}$ consider the absorption of $\mathrm{CO}_{2}$ in a biofilter filled with compost and woodchips and obtained the following function in relation to the volumetric flow rate:

$$
\left(k_{g} \cdot a\right)_{\mathrm{CO}_{2}}=69.42 \cdot\left(\frac{Q}{S}\right)^{0.46}
$$

The following functions were used for the two other variables ${ }^{[33]}$, as transport coefficients can be correlated by the diffusion coefficient (D). 


$$
\begin{aligned}
& \text { - }\left(k_{g} \cdot a\right)_{\mathrm{CH}_{4}}=\left(k_{g} \cdot a\right)_{\mathrm{CO}_{2}} \cdot \sqrt{\frac{D_{\mathrm{CH}_{4}}}{D_{\mathrm{CO}_{2}}}} \\
& \text { - }\left(k_{g} \cdot a\right)_{\mathrm{O}_{2}}=\left(k_{g} \cdot a\right)_{\mathrm{CO}_{2}} \cdot \sqrt{\frac{D_{\mathrm{O}_{2}}}{D_{\mathrm{CO}_{2}}}}
\end{aligned}
$$

In water at $25^{\circ} \mathrm{C}$ for $\mathrm{O}_{2} \mathrm{D}$ is $20 \mathrm{~cm}^{2} / \mathrm{s}$, for $\mathrm{CO}_{2}$ is $19.2 \mathrm{~cm}^{2} / \mathrm{s}$ and for $\mathrm{CH}_{4}$ is $14.9 \mathrm{~cm}^{2} / \mathrm{s}$. Generally only the diffusion coefficient in the liquid phase (water) is known but in this case the diffusion occurs in a biofilm system. In this kind of system for light gases (e.g., $\mathrm{O}_{2}, \mathrm{CO}_{2}$ or $\mathrm{CH}_{4}$ ) the ratio between the mass transfer diffusion coefficient effective and the mass transfer diffusion coefficient in the liquid phase is $0.6^{[34]}$.

\section{Michaelis-Menten kinetics}

The value chosen for Vmax was initially $8.1 \mathrm{~mol} /\left(\mathrm{m}^{3 * h}\right)^{[35]}$ and its temperature dependence was accounted for by multiplying the maximum value of the methane oxidation rate by a correction factor $f_{V, T}{ }^{[35]}$ which was assumed to be proportional to the temperature in ${ }^{\circ} \mathrm{C}$, up to a junction temperature $\mathrm{T}_{\mathrm{j}}\left(10 / \ln 2.8=9.71^{\circ} \mathrm{C}\right)$.

$$
\begin{aligned}
& f_{V, T}=2.8^{\frac{T-22^{\circ} \mathrm{C}}{10}} \quad\left(T>T_{j}\right) \\
& f_{V, T}=\frac{\ln 2.8}{10} \cdot 2.8^{\frac{1}{\ln 2.8}-2.2} \times T \quad\left(T<T_{j}\right)
\end{aligned}
$$

The parameter $K_{m}$, was also made a function of temperature. Based on the data presented by De Visscher et al. ${ }^{[35]}$ the half-saturation constant was expressed as a function of temperature (Fig. 2):

$$
\begin{array}{lll}
K_{m}=0.000729 & \text { for } T<5{ }^{\circ} \mathrm{C} & \\
K_{m}=-1.62861 \cdot 10^{-7} T^{3}+9.26 \cdot 10^{-6} \cdot T^{2}-3.54 \cdot 10^{-6} \cdot T+6.4 \cdot 10^{-4} & \text { for } 5<T<35^{\circ} \mathrm{C} \\
K_{m}=0.005171 & \text { for } T>35^{\circ} \mathrm{C} &
\end{array}
$$




\section{Sensitivity Analysis}

For the sensitivity analysis two functions were considered ${ }^{[36]}$. First, the Local Sensitivity Function $(S F)$ was calculated: $S F=\left(V^{*}-V\right) /\left(P^{*}-P\right)$; where $P$ represent the parameter value, $V$ is the variable calculated with the original parameter value while $P^{*}$ represents the perturbed parameter

value, i.e. $\left(1+10^{-3}\right) \cdot P$, and $V^{*}$ is the variable calculated with the perturbed parameter value. Then the Relative Sensitivity Function (RSF), i.e. a normalized Sensitivity Function to compare the values of each variable was calculated. This allows for comparing different sensitivity functions: $R S F=(S F \cdot P) / V$

\section{Results and Discussion}

\section{Overall operation}

The standard size of a bio-container in which occurs the oxidation and also other operating conditions are given in Table 1. These values are based on actual operational values for biofilter treating biogas with a low content of methane. Based on these values, the biofilter flow regime can be determined. The Damköhler number ( $\mathrm{Da}$ ) is 0.12 while the Stanton number is 44.11 . As such, $X=D a / S t=0.12 / 44.11=0.003$. As $X \ll 1$ the reactor is in a kinetic regime.

In these conditions the degree of methane conversion is $48.3 \%$ and the model gives the results shown in Figure 3.

\section{Influence of operational parameters}

The importance of the operational parameters such as flow rate, methane concentration and temperature on the process of methane oxidation can be determined. Some parameters mentioned in Table 1 where varied as indicated in Table 2. The effect were investigated in 3 different scenarios and presented in Figure 4. 
The results demonstrate that the increase of the flow rate value involves a worsening of the oxidative process in terms of methane conversion. This deterioration is due to the fact that increasing the flow rate decreases the residence time of the gas inside the system. The increase of the methane concentration in the gaseous flow involves a worsening of the conversion. The methane concentration in the landfill gas flow is a non-manipulatable variable of the system, being fixed by the type of gas produced by landfill. However, considering that the methane concentration in the landfill gas tends to decrease over the years, it can be expected, on the basis of these results, an improvement in time of the performance of the biofilter.

Finally, the biological processes are strongly depending on the temperature changes that takes place in the biofilter. This is mainly due to the temperature dependence of the kinetic parameters of the biological reactions (although in reality also other variables are affected, although to a lesser extent). For this reason it is important to determine the system operation by varying the temperature value inside the biofilter. As the biofilter is integrated into the landfill cover system and is not externally heated, the temperature regime of the investigated biofilter in general follows ambient temperature, with the extent varying according to the thermal conductivity of the chosen filter materials ${ }^{[16]}$. From the simulations it can be seen that the degree of methane conversion is an increasing as a function of temperature. Methane oxidation reached a maximum between 25 and $30^{\circ} \mathrm{C}$ with a consistent increased rate from 12 to $25^{\circ} \mathrm{C}^{[37]}$. Whalen et al. ${ }^{[38]}$ reported $31^{\circ} \mathrm{C}$ as optimum temperature for a landfill cover soil, King et al. ${ }^{[39]}$ reported the range $19-38{ }^{\circ} \mathrm{C}$ for pure cultures of methanotrophs.

\section{Iso-conversion graph}

From an operational point of view, it is possible to draw graphs that can be particularly useful for the biofilter in the design and subsequent management phase. This graphs show the iso-conversion curves, i.e. the locations of the points characterized by having the same values of efficiency of methane degradation. Considering three different methane mole fractions $(10 \%-20 \%-40 \%)$, two 
different values of $\mathrm{V}_{\mathrm{MAX}}\left(8.1-4 \mathrm{~mol} / \mathrm{m}^{3} * \mathrm{~h}\right)$ and defining the residence time of the gas in the reactor as $t_{p}[h]=V / Q_{T}$ (where $V$ is the effective volume of the system and $Q_{T}$ is the effective flow that arrives to the system). Simulation at a lower $\mathrm{V}_{\mathrm{MAX}}$ aimed at demonstrating the behaviour of the biofilter under sub-optimal conditions. Figure 5 is constructed considering a methane conversion range between $10 \%$ and $95 \%$.

\section{Sensitivity Analysis}

Sensitivity analysis helps to understand the dynamics of the system and the contribution of the various parameters to the model output uncertainty and the system performance in general. For this sensitivity analysis the $\mathrm{yCH}_{4}, \mathrm{yCO}_{2}$ and $\mathrm{yO}_{2}$ (molar concentrations in the gas phase exit from the biofilter) were considered as variables. The parameter values mentioned in Table 1 were used. Above it was discussed that several of these parameters are related e.g $k g * a$ is based on the applied $Q$, and also $\mathrm{Km}$ and $\operatorname{Vmax}$ are functions of the temperature. For this sensitivity analysis $\mathrm{kg} * \mathrm{a}, \mathrm{Km}$ and Vmax were disconnected from the their dependence from flow and temperature respectively. As such, a fixed value as indicated in Table 3 was used. For each parameters and for each variables it is possible to calculate the SF and the RSF and the numerical results of this calculation, using the nominal operating conditions of Table 1. The resulting sensitivities are presented in Table 3: the cells with a light gray shading have an RSF between 0,25 and 0,8 which means that they are influential. The cells with a dark grey shading have a RSF higher than 0,8 which means that they are very influential. All other cells have a RSF lower than 0,25 which means that they are not influential $^{[40]}$.

According to Table 3 the parameters that influence the system are the maximum oxidation rate of methane $\left(V_{M A X}\right)$, the half-saturation constant $(K m)$, the Temperature $(T)$ and the Flow $(Q)$. This is the reason why for the scenario analysis above $Q, y_{C H 4}$ and $T$ were used as parameters. Others models in literature found that the system is very sensitive to Vmax e.g. De Visscher et al. ${ }^{[27]}$, Stein et al. ${ }^{[26]}$. 


\section{Morris screening}

In the Morris screening ${ }^{[41]}$ the (relative) sensitivity functions of different parameters are calculated for different parameter values. This approach has been successfully applied in modelling of environmental (e.g. water) systems ${ }^{[42-43]}$. The two most influential biological parameters (maximum oxidation rate of the methane $V_{M A X}$ and the half-saturation constant $K_{m}$ ) were used. For both parameters, three different values were used, resulting in nine different parameter combinations for which a (relative) sensitivity functions was calculated. Initially the Morris screening was performed around the values proposed in literature (Vmax of $8.1 \mathrm{~mol} /\left(\mathrm{m}^{3 *} \mathrm{~h}\right)$ and $\mathrm{Km}$ of 0.003$)$. As such $\mathrm{Vmax}$ values of $7.9,8.1$ and $8.3 \mathrm{~mol} /\left(\mathrm{m}^{3 *} \mathrm{~h}\right)$ and $\mathrm{Km}$ values of $0.001,0.003$ and 0.005 were used. In a second screening, the Vmax range was extended to 4,6 and $8.1 \mathrm{~mol} /\left(\mathrm{m}^{3 *} \mathrm{~h}\right)$ in order to see the effect of a broader Vmax range. The values for $\mathrm{Km}$ were left unchanged. As such in total 18 different combinations of $\mathrm{Vmax}$ and $\mathrm{Km}$ were used in the Morris screening and the calculation of the local sensitivity functions.

With the global results of the Morris screening (using the nominal operating conditions of Table 1) it's possible to achieve a simple statistical analysis to calculate the average and the standard deviation of these 18 calculated RSF for Km and Vmax (Table 4).

The values demonstrate once again that Vmax is the most important parameter for the model. While it may be acceptable to use an Vmax only as function of temperature, there remains the problem of determining what magnitude to use. The Vmax parameter is a function of several variables, including soil particle-size distribution, moisture content, gas concentrations, nutrient status, and $\mathrm{pH}$ ${ }^{[26]}$. According to the work of Hilger et al. ${ }^{[25]}$, the accumulation of exopolymeric substances (slime) produced by the methanotrophic bacteria is also an important factor controlling Vmax. As such, careful determination of Vmax is important. 


\section{Conclusions}

A novel model was developed in this work to describe the methane oxidation in a biofilter. The model was developed for the most important biogas components (methane, oxygen and carbon dioxide) and considers several parameters such as gas transport, temperature, flow quantity, gas concentration. The sensitivity analysis has shown that the model is most sensitive to Vmax, so this parameter need to be determined accurately.

The behaviour of the model was investigated from a theoretical point of view using the data available in literature. Specifically, it was found that temperature, flow and methane concentration are the most important parameters that influence the system. The iso-conversion curves give practical informations to design and manage a biofilter.

Future work should be focussing on developing lab-scale and field-scale biofilter in order to accurately determine the most sensitive parameter, $\mathrm{V}_{\max }$ and extend the model beyond the current knowledge (e.g. temperature higher than $30^{\circ} \mathrm{C}$ and different environmental conditions). Data from such systems can be used for model testing and validation.

\section{Acknowledgments}

The authors would like to thank the Ateneo of University of Basilicata for its financial support which has enabled the collaboration with Ghent University.

\section{References}

[1] Forster, P.; Ramaswamy, V.; Artaxo, P.; Berntsen, T.; Fahey, D.W. Changes in atmospheric constituents and in radiative forcing. In Climate Change 2007: The Physical Science Basis. Contribution of Working Group I to the Fourth Assessment Report of the Intergovernmental Panel on Climate Change; Solomon, S.; Qin, D.; Manning, M.; Chen, Z.; Marquis, M.; Averyt, K.B.; Tignor, M.; Miller, H.L. Eds.; Cambridge University Press, Cambridge, 2007, UK and New York, NY, USA. 
[2] Bogner, J.; Abdelrafie Ahmed, M.; Diaz, C.; Faaij, A.; Gao, Q.; Hashimoto, S.; Mareckova, K.; Pipatti, R.; Zhang., T. Waste management. In Climate Change: Mitigation Contribution of Working Group III to the Fourth Assessment Report of the Intergovernmental Panel on Climate Change; Metz, B.; Davidson, O.R.; Bosch, P.R.; Dave, R.; Meyer, L.A. Eds.; Cambridge University Press, Cambridge, United Kingdom and New York, NY, USA, 2007; $34 \mathrm{pp}$.

[3] Scheutz, C.; Kjeldsen, P.; Bogner, J.E.; De Visscher, A.; Gebert, J.; Hilger, H. A.; HuberHumer, M. ; Spokas, K. Microbial methane oxidation processes and technologies for mitigation of landfill gas emissions. Waste Management and Research 2009, 27, 409-455.

[4] IPCC. Summary for policymakers. In Climate Change 2007: The Physical Science Basis. Contribution of Working Group I to the Fourth Assessment Report of the Intergovernmental Panel on Climate Change; Solomon, S.; Qin, D.; Manning, M.; Chen, Z.; Marquis, M.; Averyt, K.B.; Tignor, M.; Miller, H.L. Eds.; Cambridge University Press, Cambridge, 2007, UK and New York, NY, USA.

[5] US-EPA, US Emission Inventory 2009. Inventory of U.S. Greenhouse gas emissions and sinks: 1990-2007. Public Review Draft, 2009.

http://www.epa.gov/climatechange/emissions/usinventoryreport.html. Accessed April 2009.

[6] EEA (European Environment Agency). Annual European Community Greenhouse Gas Inventory 1990-2006 and Inventory Report 2008. Submission to the UNFCCC Secretariat. EEA Technical report, no. 6. 2008. ISSN 1725-2237.

http://www.eea.europa.eu/publications/technical_report_(2008_6). Accessed April 2009.

[7] Cosmi, C.; Cuomo, V.; Macchiato, M.; Mangiamele, L.; Masi, S.; Salvia M. Waste management modeling by MARKAL model: A case study for Basilicata Region. Environmental Modeling and Assessment 2000, 5, 19-27.

[8] Pnr Engineering Systems - Specialists in process instrumentation \& heat exchanger services http://www.pnr-engineering.com.sg/wp-content/uploads/flare.pdf. Accessed April 2014. 
[9] Melse, R.W.; Van der Werf, A. Biofiltration for mitigation of methane emission from animal husbandry. Environmental Science and Technology 2005, 39, 5460-5468.

[10] Streese, J.; Stegman, R. Microbial oxidation of $\mathrm{CH}_{4}$ from old landfills in biofilters. Waste Management 2003, 23, 573-580.

[11] Du Plessis, C.A.; Strauss, J.M.; Sebapalo, E.M.T.; Riedel, K.-H.J. Empirical model for methane oxidation using a composted pine bark biofilter. Fuel 2003, 82, 1359-1365.

[12] Haubrichs, R.; Widmann, R. Evaluation of aerated biofilter systems for microbial methane oxidation of poor landfill gas. Waste Management 2006; 26, 408-416.

[13] Wilshusen, J.H.; Hettiaratchi, J.P.A.; Stein, V.B. Long-term behaviour of passively aerated compost methanotrophic biofilter columns. Waste Management 2004, 24, 643-653.

[14] Straka, F.; Crha, J.; Musilova, M.; Kuncarova, M. Biofilters on old landfills. In Proc. Sardinia 1999. Seventh International Waste Management and Landfill Symposium, 2, 507-516; Christensen, T.H.; Cossu, R.; Stegmann, R. Eds.; Seventh International Waste Management and Landfill Symposium, CISA; Cagliari, Italy, 1999.

[15] Dever, S.A.; Swarbrick, G.E.; Stuetz, R.M. Passive drainage and biofiltration of landfill gas using recycled waste materials under Australian conditions. In: Proceedings Sardinia '05; Tenth International Waste Management and Landfill Symposium; 3-7 October 2005. CISA, Cagliari, Italy, 2005.

[16] Gebert, J.; Gröngröft, A. Performance of a passively vented field-scale biofilter for the microbial oxidation of landfill methane. Waste Management 2006, 26, 399-407.

[17] Chanton, J.P.; Powelson, D.K.; Green, R.B. Methane oxidation in landfill cover soils; is a 10\% default value reasonable? Journal of Environmental Quality 2009, 38, 654-63.

[18] Ng, C.W.W.; Feng, S.; Liu H.W. A fully coupled model for water-gas-heat reactive transport with methane oxidation in landfill covers. Science of the Total Environment 2015, 508, $307-$ 319. 
[19] Abichou, T.; Mahieu, K.; Chanton, J.; Romdhane, M.; Mansouri, I. Scaling methane oxidation: from laboratory incubation experiments to landfill cover field conditions. Waste Management 2011, 31, 978-86.

[20] Wang, J.; Xia, F.; Bai, Y.; Fang, C.; Shen, D.; He, R. Methane oxidation in landfill waste biocover soil: Kinetics and sensitivity to ambient conditions. Waste Management 2011, 31, 864-870.

[21] Einola, J.K.M.; Kettunen, R.H. \& Rintala, J.A. Responses of methane oxidation to temperature and water content in cover soil of a boreal landfill. Soil Biology and Biochemistry 2007, 39, 1156-1164.

[22] Park, S.; Brown, K.W.; Thomas, J.C. The effect of various environmental and design parameters on methane oxidation in a model biofilter. Waste Management and Research 2002, 20, 434-444.

[23] Cabral, A.R.; Tremblay, P.; Lefebvre, G. Determination of the diffusion coefficient of oxygen for a cover system composed of pulp and paper residues. ASTM Geotechnical Testing Journal 2004, 27, 184-197.

[24] Bogner, J.E.; Spokas, K.A.; Burton, E.A.; Kinetics of methane oxidation in a landfill cover soil: Temporal variations; a wholelandfill oxidation experiment; and modeling of net $\mathrm{CH}_{4}$ emissions. Environmental Science \& Technology 1997, 31, 2504-2514.

[25] Hilger, H. A.; Cranford, D. F.; Barlaz, M. A. Methane oxidation and microbial exopolymer production in landfill cover soils.' Soil Biol. Biochem. 1999, 32, 457-467.

[26] Stein, V.B.; Hettiaratchi, J.P.A.; Achari, G. Numerical model for biological oxidation and migration of methane in soils. Practice Periodical of Hazardous Toxic and Radioactive Waste Management 2001, 5, 225-234.

[27] De Visscher, A.; Van Cleemput, O. Simulation model for gas diffusion and methane oxidation in landfill cover soils. Waste Management 2003, 23, 581-599. 
[28] Hettiarachchi, V.C.; Hettiaratchi, J. P. A.; Mehrotra, A. K. Comprehensive One-Dimensional Mathematical Model for Heat; Gas; and Moisture Transport in Methane Biofilters. Practice Periodical of Hazardous; Toxic and Radioactive Waste Management 2007, 11 (4), 225-234.

[29] Hettiarachchi, V.C.; Hettiaratchi, J. P.; Mehrotra, A. K.; Kumar, S. Field-scale operation of methane biofiltration systems to mitigate point source methane emissions. Environmental pollution 2011, 159, 1715-1720.

[30] Abichou, T.; Kormi, T.; Yuan, L.; Johnson, T.; Francisco, E. Modeling the effects of vegetation on methane oxidation and emissions through soil landfill final covers across different climates. Waste Management 2015, 36, 230-240.

[31] Sander, R. Compilation of Henry's Law Constants for Inorganic and Organic Species of Potential Importance in Environmental Chemistry (Version 3)" http://www.henrys-law.org. Accessed April 2014.

[32] Seongyup, K.; Deshusses, M. A. Determination of mass transfer coefficients for packing materials used in biofilters and biotrickling filters for air pollution control. Experimental results. Chemical Engineering Science 2008, 63, 841 - 855 .

[33] Van Hulle, S.W.H.; Callensa, J.; Mampaey, K.E.; Van Loosdrecht, M.C.M.; Volcke, E.I.P. $\mathrm{N}_{2} \mathrm{O}$ and $\mathrm{NO}$ emissions during autotrophic nitrogen removal in a granular sludge reactor - a simulation study. Environmental Technology 2012, 33 (20).

[34] Stewart, P.S. Diffusion in biofilm. Journal of Bacteriology 2003, 185 (5), 1485-1491.

[35] De Visscher, A.; Schippers, M.; Van Cleemput, O. Short-term kinetic response of enhanced methane oxidation in landfill cover soils to environmental factors. Biology and Fertility of Soils 2001, 33, 231-237.

[36] De Pauw, D.J.W.; Vanrolleghem, P.A. Practical aspects of sensitivity function approximation for dynamic models. Mathematical and Computer Modelling of Dynamical Systems 2006, 12, (5), 395-414. 
[37] Boeckx, P.; Van Cleemput O. Methane Oxidation in a Neutral Landfill Cover Soil: Influence of Moisture Content; Temperature; And Nitrogen-Turnover. Journal of Environmental Quality 1996, 25 (1).

[38] Whalen, S.C.; Reeburgh, W.S.; Sandbeck, K.A. Rapid methane oxidation in a landfill cover soil. Applied and Environmental Microbiology. Applied and Environmental Microbiology 1990, 56, 3405-3411.

[39] King, G.M.; Adamsen, A.P.S. Effects of Temperature on methane consumption in a forest soil and in a pure cultures of methanotroph Methylomonas rubra. Appl. Enviorn. Microb. 1992, $58,2758-2763$.

[40] Jiang, T.; Liu, X.; Kennedy, M.D.; Schippers, J.C.; Vanrolleghem, P.A. Calibrating a sidestream membrane bioreactor using Activated Sludge Model No. 1. Water Science and Technology 2005, 52 (10-11), 359-367.

[41] Morris, M.D. Factorial sampling plans for preliminary computational experiments. Technometrics 1991, 33, 161-174.

[42] Ruano, M.V.; Ribes, J.; Ferrer, J.; Sin, G. Application of the Morris method for screening the influential parameters of fuzzy controllers applied to wastewater treatment plants. Water Science Technology 2011, 63, 2199-2206.

[43] Vezzaro, L.; Eriksson, E.; Ledin, A.; Mikkelsen, P.S. Modelling the fate of organic micropollutants in stormwater ponds. Science of the Total Environment 2011, 409, 25972606. 


\section{FIGURE CAPTIONS}

Figure 1. Cross-sectional details of the Biofilter

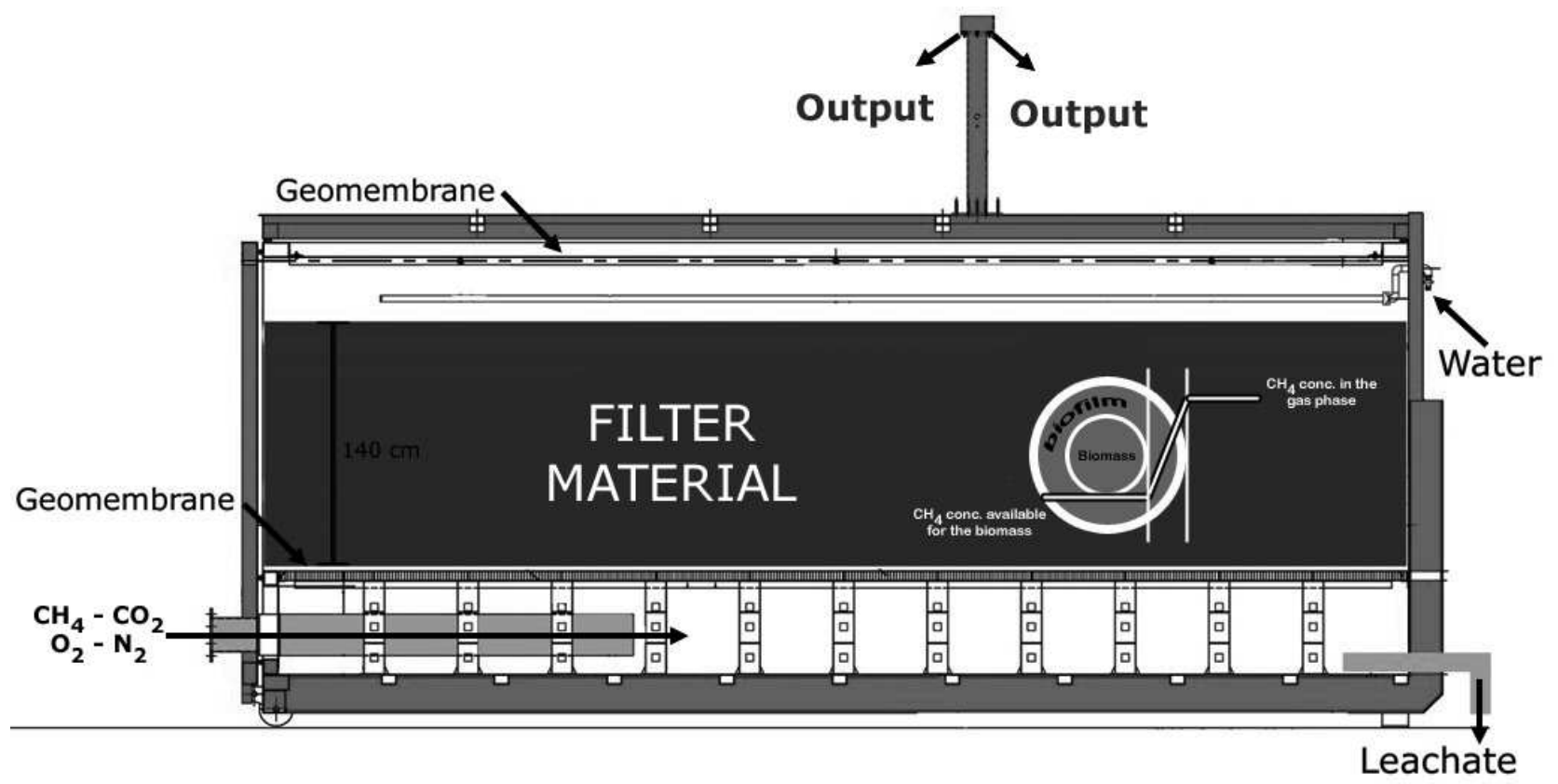

Figure 2. Variation law of $\mathrm{Km}$ (dimensionless) as a function of temperature

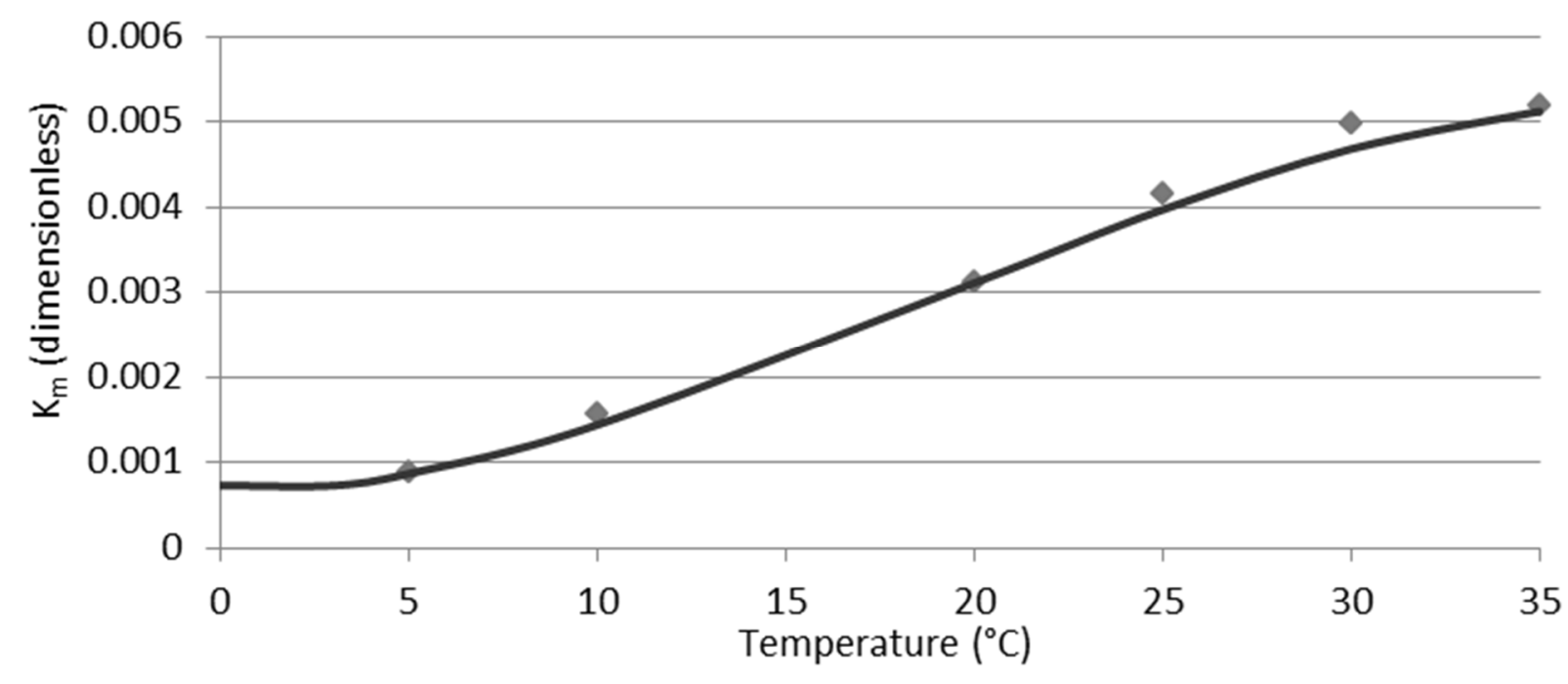


Figure 3. Variation of the mole fraction as a function of the biofilter height

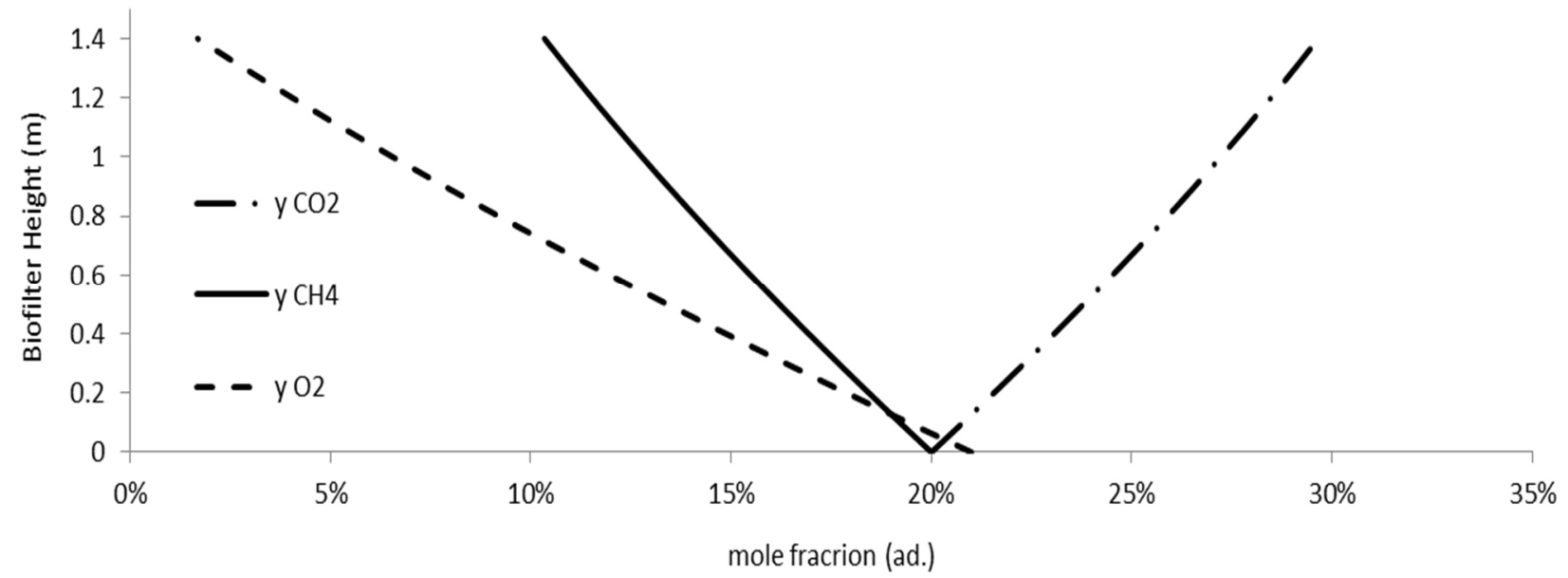


Figure 4. Variation of the degree of methane conversion $\mathrm{x}_{\mathrm{CH} 4}$ as a function of the biofilter height by varying: a) the flow from 10 to $100 \mathrm{Nm}^{3} / \mathrm{h}$ (scenario 1 ); b) the methane mole fraction from $5 \%$ to $50 \%$ (scenario 2); c) the temperature from 1 to $30^{\circ} \mathrm{C}$ (scenario 3 ).
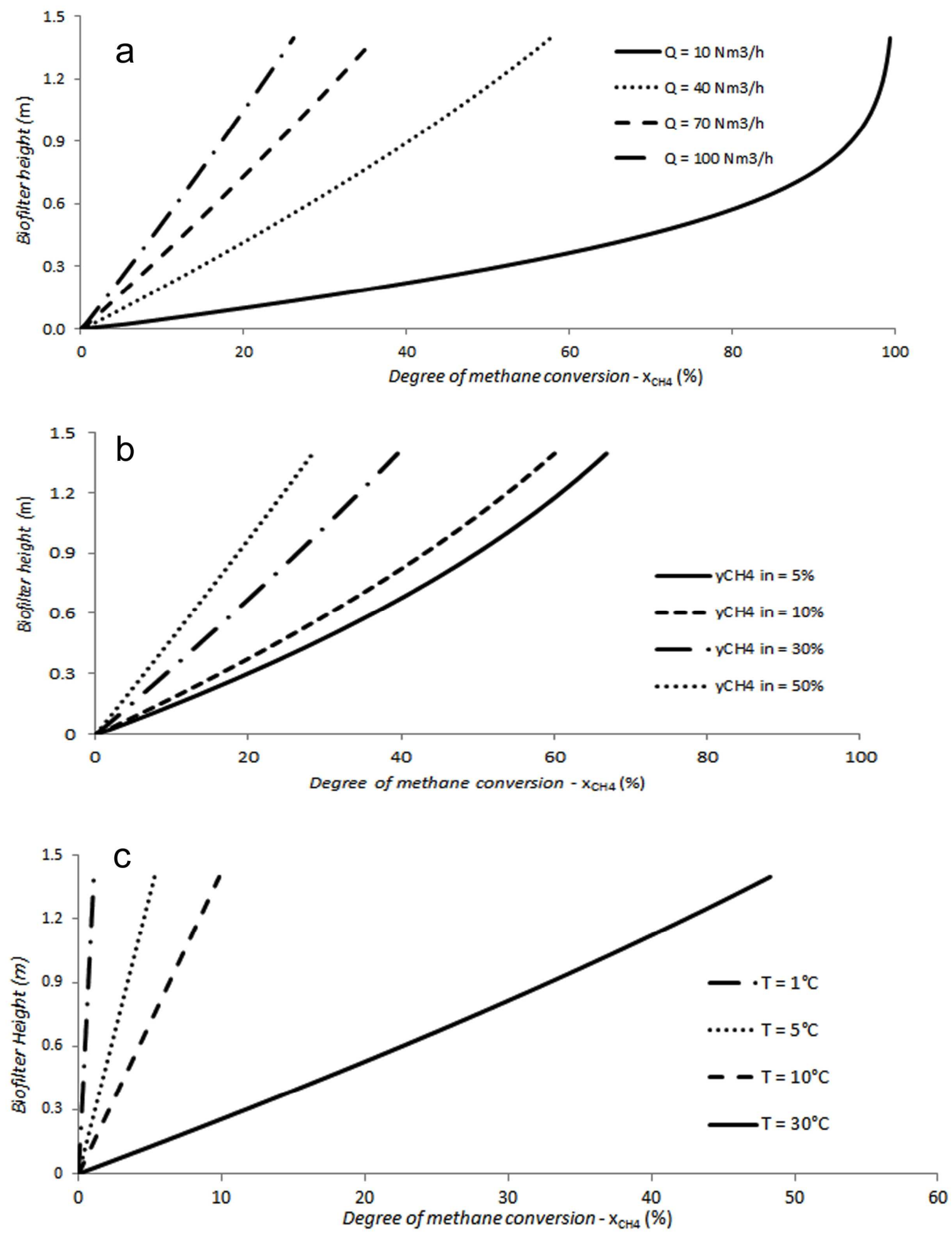
Figure 5. Iso-conversion curves for a biofilter $\left(\mathrm{V}=22.75 \mathrm{~m}^{3}\right)$ as a function of the residence time of the landfill gas and of the temperature of the system with these conditions: a) $\mathrm{y}_{\mathrm{CH} 4}=10 \%-\mathrm{V}_{\mathrm{MAX}}=$ $8.1 \mathrm{~mol} /\left(\mathrm{m}^{3} * \mathrm{~h}\right)$ b) $\left.\left.\mathrm{yCH}_{4}=20 \%-\mathrm{V}_{\mathrm{MAX}}=8.1 \mathrm{~mol} /\left(\mathrm{m}^{3} * \mathrm{~h}\right) \mathrm{c}\right) \mathrm{yCH}_{4}=40 \%-\mathrm{V}_{\mathrm{MAX}}=8.1 \mathrm{~mol} /\left(\mathrm{m}^{3} * \mathrm{~h}\right) \mathrm{d}\right)$ $\mathrm{y}_{\mathrm{CH}} 4=10 \%-\mathrm{V}_{\mathrm{MAX}}=4 \mathrm{~mol} /\left(\mathrm{m}^{3} * \mathrm{~h}\right)$ e) $\left.\mathrm{y}_{\mathrm{CH} 4}=20 \%-\mathrm{V}_{\mathrm{MAX}}=4 \mathrm{~mol} /\left(\mathrm{m}^{3} * \mathrm{~h}\right) \mathrm{f}\right) \mathrm{yCH}_{4}=40 \%-\mathrm{V}_{\mathrm{MAX}}=4$ $\mathrm{mol} /\left(\mathrm{m}^{3 *} \mathrm{~h}\right)$.
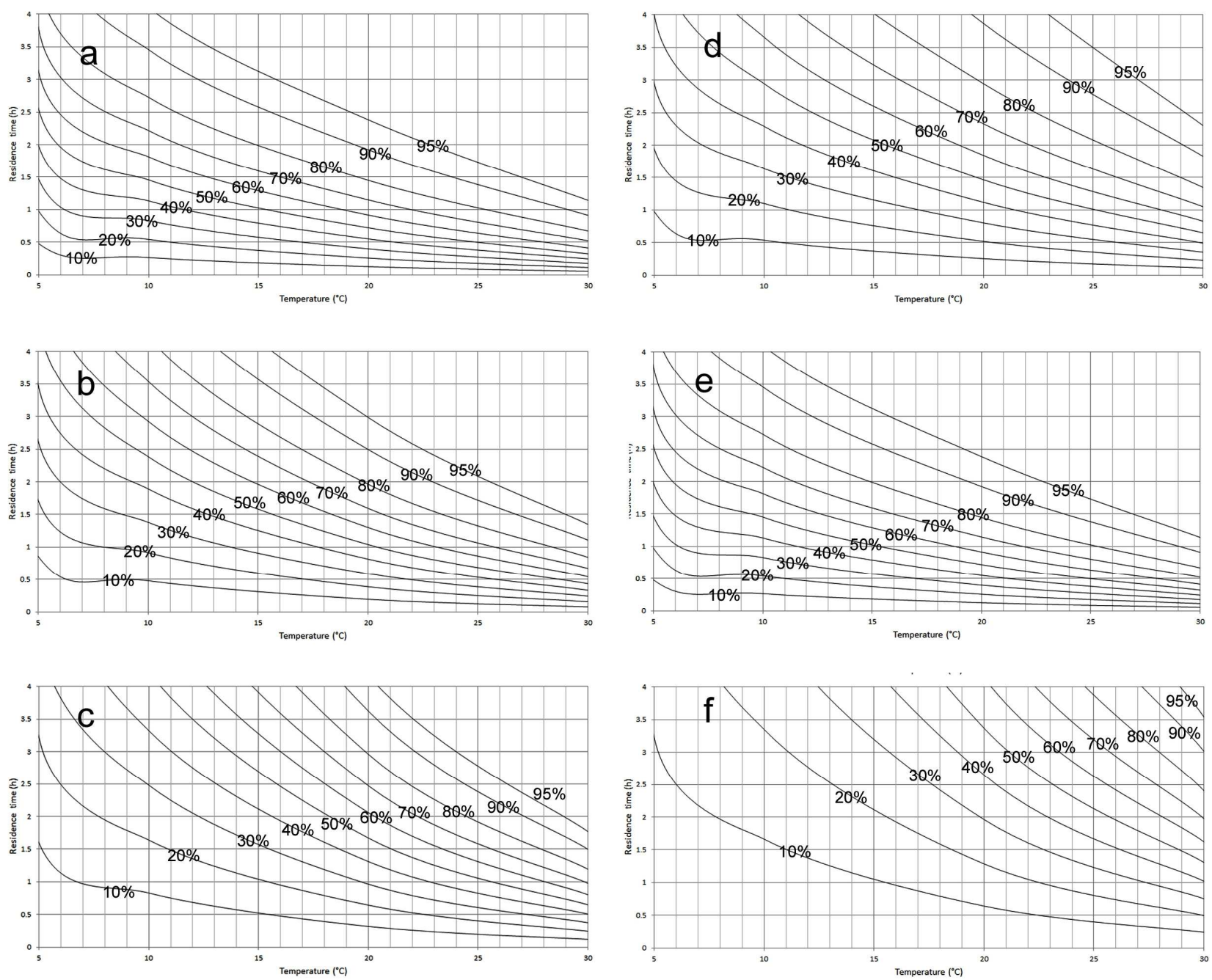
Table 1. Nominal operating conditions of the aerobic biofilter

\begin{tabular}{ccc}
\hline Parameters & Values & UM \\
Length & 6.5 & $\mathrm{~m}$ \\
Width & 2.5 & $\mathrm{~m}$ \\
Height & 1.4 & $\mathrm{~m}$ \\
Surface & 16.25 & $\mathrm{~m}^{2}$ \\
Volume & 22.75 & $\mathrm{~m}^{3}$ \\
$\mathrm{Q}$ & 50 & $\mathrm{Nm}^{3} / \mathrm{h}$ \\
$\mathrm{T}$ & 30 & ${ }^{\circ} \mathrm{C}$ \\
$\mathrm{C}_{\text {тот. }}$ & 43.8 & $\mathrm{~mol} / \mathrm{m}^{3}$ \\
$\mathrm{CH}_{4}$ & 20 & $\%$ \\
$\mathrm{CO}_{2}$ & 20 & $\%$ \\
$\mathrm{O}_{2}$ & 21 & $\%$ \\
\hline
\end{tabular}

Table 2. Operating conditions used in the simulations for scenario analysis

\begin{tabular}{ccccc}
\hline Parameters & Scenario 1 & Scenario 2 & Scenario 3 & UM \\
$\mathrm{Q}$ & Variable & 50 & 50 & $\mathrm{Nm}^{3} / \mathrm{h}$ \\
$\mathrm{T}$ & 30 & 30 & Variable & ${ }^{\circ} \mathrm{C}$ \\
$\mathrm{C}_{\text {Tот. }}$ & 43.8 & 43.8 & 43.8 & $\mathrm{~mol} / \mathrm{m}^{3}$ \\
$\mathrm{CH}_{4}$ & 20 & Variable & 20 & $\%$ \\
$\mathrm{CO}_{2}$ & 20 & 20 & 20 & $\%$ \\
$\mathrm{O}_{2}$ & 21 & 21 & 21 & $\%$ \\
\hline
\end{tabular}


Table 3. Values of Sensitivity Functions

\begin{tabular}{|c|c|c|c|c|c|c|c|}
\hline & \multirow{2}{*}{$\begin{array}{l}\text { Normal } \\
\text { Value }\end{array}$} & \multicolumn{2}{|c|}{$\left[\mathrm{CH}_{4}\right]$} & \multicolumn{2}{|c|}{$\left[\mathrm{CO}_{2}\right]$} & \multicolumn{2}{|c|}{$\left[\mathrm{O}_{2}\right]$} \\
\hline & & $\mathrm{SF}$ & RSF & $\mathrm{SF}$ & RSF & $\mathrm{SF}$ & RSF \\
\hline Km [dimensionless] & 0.005 & 372.60 & 0.44 & 372.60 & 0.14 & 745.21 & 0.93 \\
\hline $\mathrm{Vmax}\left[\mathrm{mol} /\left(\mathrm{m}^{3 *} \mathrm{~h}\right)\right]$ & 8.1 & 0.48 & 1.04 & 0.48 & 0.29 & 0.97 & 2.48 \\
\hline $\mathrm{Kg}^{*} \mathrm{a} \mathrm{CH}_{4}\left[\mathrm{~h}^{-1}\right]$ & 102.55 & 0.00 & 0.01 & 0.00 & 0.00 & 0.00 & 0.01 \\
\hline $\mathrm{Kg}^{*} \mathrm{a} \mathrm{CO}_{2}\left[\mathrm{~h}^{-1}\right]$ & 116.41 & 0.00 & 0.00 & 0.00 & 0.00 & 0.00 & 0.00 \\
\hline $\mathrm{Kg}^{*} \mathrm{a} \mathrm{O}{ }_{2}\left[\mathrm{~h}^{-1}\right]$ & 104.67 & 0.00 & 0.00 & 0.00 & 0.00 & 0.00 & 0.00 \\
\hline $\mathrm{T}\left[{ }^{\circ} \mathrm{C}\right]$ & 25 & 0.33 & 2.19 & 0.33 & 0.60 & 0.66 & 5.23 \\
\hline $\mathrm{Q}\left[\mathrm{Nm}^{3} / \mathrm{h}\right]$ & 50 & 0.08 & 1.04 & 0.08 & 0.29 & 0.16 & 2.49 \\
\hline
\end{tabular}

Table 4. Average value (with standard deviation) of the calculated relative sensitivity functions calculated during the Morris screening

\begin{tabular}{rcccc}
\hline Variable & \multicolumn{2}{c}{ Vmax } & \multicolumn{2}{c}{$\mathrm{Km}$} \\
\hline & \multicolumn{2}{c}{ Applied Vmax values: } & \multicolumn{2}{c}{ Applied Vmax values: } \\
\cline { 2 - 5 } $\mathrm{CH}_{4}$ & $7.9-8.1-8.3$ & $4-6-8.1$ & $7.9-8.1-8.3$ & $4-6-8.1$ \\
\cline { 2 - 5 } $\mathrm{CO}_{2}$ & $0.76 \pm 1.04$ & $0.4515 \pm 0.1856$ & $0.57 \pm 0.14$ & $0.0081 \pm 0.0062$ \\
$\mathrm{O}_{2}$ & $5.12 \pm 3.68$ & $1.7872 \pm 1.2555$ & $1.6 \pm 0.63$ & $0.0250 \pm 0.0224$ \\
\hline
\end{tabular}

